\title{
Pengaruh Disiplin Dan Lingkungan Kerja Terhadap Kinerja Pegawai Satuan Polisi Pamong Praja Kota Prabumulih
}

\author{
Muhammad Deni \\ Universitas Sjakhyakirti Palembang \\ Email:muhammaddeni1775@gmail.com
}

\begin{abstract}
ABSTRAK
Penelitian ini bertujuan untuk mengetahui : (1) Pengaruh Disiplin terhadap Kinerja Pegawai Satuan Polisi Pamong Praja Kota Prabumulih, (2) Pengaruh Lingkungan Kerja terhadap Kinerja Pegawai Satuan Polisi Pamong Praja Kota Prabumulih, (3) Pengaruh disiplin dan lingkungan kerja terhadap Kinerja Pegawai Satuan Polisi Pamong Praja Kota Prabumulih.

Penelitian ini dikategorikan sebagai penelitian survey, dimana instrumen penelitian ini berupa kuesioner. Sampel dalam penelitian ini berjumlah 112 orang. Analisis data yang digunakan dalam penelitian ini adalah analisis regresi linear berganda dengan uji $t$ dan ujif.

Hasil penelitian mengemukakan bahwa : (1) Disiplin berpengaruh secara parsial terhadap kinerja pegawai Satuan Polisi Pamong Praja Kota Prabumulih.;

(2) Lingkungan Kerja berpengaruh secara parsial terhadap kinerja pegawai Satuan Polisi Pamong Praja Kota Prabumulih ; (3) Disiplin dan Lingkungan Kerja berpengaruh secara simultan terhadap kinerja pegawai Satuan Polisi Pamong Praja Kota Prabumulih.

Kata kunci : Disiplin, Lingkungan Kerja, Kinerja
\end{abstract}

\section{PENDAHULUAN}

\section{LATAR BELAKANG}

Keberhasilan suatu perusahaan tidak selalu diukur oleh seberapa besar uangyang dimiliki melainkan ada hal lain yang lebih penting yaitu Sumber Daya Manusia (SDM) yang berada di perusahaan. Dalam era globalisasi saat ini sangat diperlukan SDM yang bermutu karena maju mundurnya suatu perusahaan sangat tergantung pada kualitas SDM atau karyawannya. Semakin baik kualitas 
karyawan suatu perusahaan maka semakin tinggi daya saing perusahaan tersebut terhadap perusahaan lainnya. Karyawan adalah aset berharga yang perlu diperhatikan dan dibina dengan baik sehingga perusahaan harus memperhatikan setiap detil program-program yang berkaitan dengan pengembangan sumber daya manusia guna menghasilkan karyawan yang kompeten dan berdaya saing tinggi. (Aditya,2016).

Seperti halnya Satuan Polisi Pamong Praja Kota Prabumulihyang yang memiliki banyak pegawai untuk membantu Kepala Daerah dalam mencapai tujuan yang diharapkan. Dalam rangka penegakkan Perda, unsur utama sebagai pelaksana di lapangan adalah Pemda ataupun Pemkot. Dalam hal ini kewenangan tersebut diemban oleh Satuan Polisi Pamong Praja (Satpol PP). Satpol PP mempunyai tugas membantu Kepala Daerah untuk menciptakan suatu kondisi daerah yang tentram, tertib, dan teratur sehingga penyelenggaraan roda pemerintahan dapat berjalan dengan lancar dan masyarakat dapat melakukan kegiatannya dengan aman. Oleh karena itu, di samping menegakkan Perda, Satpol PP juga dituntut untuk menegakan kebijakan Pemda lainnya, yaitu peraturan Kepala Daerah. Memang saat ini berbagai peraturan yang buat oleh Kepala Daerah belum disosialisasikan secara optimal, sehingga pemahaman masyarakat akan pentingnya Perda ini amat dangkal. Namun di lain pihak, penegakkan peraturan tidak memberikan rasa dan kesan keadilan bagi masyarakat. Aparat Satpol PP sendiri kadang kala melakukan tindakan setelah pelanggaran tersebut sudah terakumulasi, sehingga dalam penegakannya memerlukan tenaga, biaya, dan pikiran yang cukup berat. Hampir sebagian dari pegawai Satuan Polisi Pamong Praja Kota Prabumulih baik Aparatur Sipil Negara (ASN) maupun Pegawai Harian Lepas (PHL) belum menunjukkan kinerja yang optimal baik dari segi kedisplinan dalam berpakaian ataupun ketaatan jam kerja.

Selain itu, Pegawai Satpol PP Kota Prabumulih masih mengabaikan beberapa tugasyang menjadi kewajibannya, seperti mengabaikan surat perintah tugas, meninggalkan tempat piket, tidak mengikuti apel yang pada dasarnya apel tersebut merupakan tugas wajib yang harus dikuti setiap harinya.Pada kasus ini terlihat bagaimana masih rendahnya tanggungjawab pegawaidalam melakukan tugas yang diamanahkan kepadanya. Hal ini menandakanbahwa pegawaiSatpol PP 
Kota Prabumulih kurang dapat mematuhi tupoksi yang telah ditetapkan oleh Instansi.

Fenomena lain yang masih sering ditemui adalah kurang adanya rasa hormatkepada atasan yang jabatan atau posisinya lebih tinggi dari pegawai lainnya,seperti memanggil nama yang bersangkutan secara langsung. Pegawai terlalumenganggap dirinya sangat dekat dengan atasannya sehingga menimbulkan rasakurang hormat terhadap atasannya. Hal ini mengindikasikan bahwa pegawaidinilai belum mampu bekerja secara etis.Selain itu faktor motivasi karyawanyang kurang stabil dan beban kerja yang cukup tinggi serta kepuasan kerja yangdirasakan oleh pegawai juga dinilai belum maksimal sehingga kinerja pegawai menurun.

\section{KAJIAN PUSTAKA}

\section{Disiplin}

Ronquilla (word Press) kata disiplin berasal dari bahasa latin Discerre yang berarti belajar. Dari kata ini timbul Displin yang berarti pengajaran atau pelatihan. Disiplin adalah kondisi kendali dari pegawai atau karyawan dan perilaku tertib yang menunjukkan tingkat kerja sama yang sesungguhnya dalam salah satu organisasi. Salah satu aspek hubungan internal pegawai atau karyawan adalah tindakan displiner. Tindakan disipliner (disciplinary action) menegakkan sanksi apabila ia melanggar tugas yang diberikan. Disiplin adalah sikap kesediaan dan kerelaaan seseorang untuk mematuhi dan menaati norma-norma peraturan yang berlaku di sekitarnya. Menurut Keith Davis disiplin kerja dapat diartikan sebagai pelaksanaan manajemen untuk memperteguh pedoman-pedoman organisasi. Disiplin kerja adalah suatu alat yang digunakan para manajer untuk berkomunikasi dengan bawahannya agar mereka bersedia meningkatkan kesdaran seseorang mentaati semua peraturan dan norma-norma sosial yang berlaku.

\section{Lingkungan Kerja}

Lingkungan kerja dalam suatu perusahaan perlu diperhatikan, hal ini disebabkan karena lingkungan kerja mempunyai pengaruh langsung terhadap para 
karyawan. Lingkungan kerja yang kondusif dapat meningkatkan kinerja karyawan dan sebaliknya, lingkungan kerja yang tidak memadai akan dapat menurunkan kinerja karyawan. Kondisi lingkungan kerja dikatakan baik apabila manusia dapat melaksanakan kegiatan secara optimal, sehat, aman dan nyaman. Kesesuaian lingkungan kerja dapat dilihat akibatnya dalam jangka waktu yang lama.

Lingkungan kerja yang kurang baik dapat menuntut tenaga kerja dan waktu yang lebih banyak dan tidak mendukung diperolehnya rancangan sistem kerja yang efisien.

1. Menurut Robbins (2003) lingkungan adalah lembaga-lembaga atau kekuatan-kekuatan diluar yang berpotensi mempengaruhi kinerja organisasi, lingkungan dirumuskan menjadi dua yaitu lingkungan umum dan lingkungan khusus. Lingkungan umum adalah segala sesuatu di luar organisasi yang memilki potensi untuk mempengaruhi organisasi. Lingkungan ini berupa kondisi sosial dan teknologi. Sedangkan lingkungan khusus adalah bagian lingkungan yang secara langsung berkaitan dengan pencapaian sasaran-sasaran sebuah organisasi.

2. Menurut Basuki dan Susilowati (2005) lingkungan kerja adalah segala sesuatu yang berada di lingkungan yang dapat mempengaruhi baik secara langsung maupun tidak langsung seseorang atau sekelompok orang di dalam melaksanakan aktivitasnya.

\section{Kinerja}

Kinerja dalam sebuah organisasi merupakan salah satu unsur yang tidak dapatdipisahkan dalam suatu organisasi, baik itu organisasi publik maupun organisasiswasta. Kinerja organisasi akan sangat ditentukan oleh unsur pegawainya, karenaitu dalam mengukur kinerja suatu organisasi sebaiknya diukur dalam tampilan kerja dari pegawainya.Istilah kinerja berasal dari kata Job Performance atau Actual Performanceyang merupakan prestasi kerja atau prestasi sesungguhnya yang dicapai oleh seseorang.

Mangkunegara (2011) mengatakan, kinerja adalah hasil kerja secara kualitas dan kuantitas yang dicapai oleh seseorang pegawai dalam melaksanakan tugasnya sesuai dengan tanggung jawab yang diberikan kepadanya. Menurut 
Gibson dalam Nawawi (2013) mengemukakan bahwa kinerja seseorang di tentukan oleh kemampuan dan motivasinya untuk melaksanakan pekerjaan. Selanjutnya dikatakan pelaksanaan pekerjaan ditentukan oleh interaksi kemampuan dan motivasi. Sedangka Prawirosentono dalam Sutrisno (2011) mengemukakan kinerja adalah hasil kerja dapat dicapai oleh seseorang atau kelompok orang dalam suatu organisasi, sesuai dengan wewenang dan tanggung jawab masing - masing dalam rangka upaya mencapai tujuan organisasi bersangkutan secara legal, tidak melanggar hukum, dan sesuai dengan moral maupun etika. Selanjutnya menurut hasibuan (2007) menjelaskan bahwa kinerja adalah suatu hasil kerja yang dicapai seseorang dalam melaksanakan tugas-tugas yang dibebankan kepadanya yang didasarkan atas kecakapan, pengalaman, dan kesungguhan serta waktu.

\section{METODOLOGI PENELITIAN}

\section{Desain Penelitian}

Desain penelitian yang dilakukan dalam penelitian ini adalah Penelitian ini dapat digolongkan ke dalam jenis penelitian asosiatif (Pengaruh), Yakni penelitian ini untuk mengetahui Pengaruh Disiplin

dan Lingkungan Kerja Terhadap Kinerja Pegawai Satuan Polisi Pamong Praja Kota Prabumulih.

\section{Lokasi Penelitian}

Lokasi penelitian dilakukan melalui Pegawai Satuan Polisi Pamong Praja Kota Prabumulih. Penetapan Unit analisis ini didasarkan pada Disiplin dan Lingkungan Kerja terhadap Pegawai Satuan Polisi Pamong Praja Kota Prabumulih.

\section{Metode Pengumpulan dan Analisa Data}

Teknik pengambilan data dalam penelitian ini adalah data primer dan data sekunder, yaitu dengan cara mengadakan teknik survey, observasi dan dengan dokumentasi. Teknik analisa data tersebut meliputi:

(1) Uji Validitas 
Uji validitas untuk mengetahui kelayakan butir-butir dalam suatu daftar (konstruk) pertanyaan dalam mendefenisikan suatu variabel. Menilai masing-masing butir pertanyaan dapat dilihat dari nilai corrected item-total correlation (Bhuono Agung Nugroho, 2015, h.67-68). Suatu butir pertanyaan dikatakan valid jika pernyataan pada kuesioner mampu diukur. Cara pengujian validitas dengan menghitung kolerasi antar skor masing-masing pernyataan dan skor total dengan menyimpulkan jika nilai rhitung $>$ rtabel product moment maka butir soal kuesioner dinyatakan valid, sementara jika nilai $r$ hitung $<r$ tabel maka butir soal kesioner dinyatakan tidak validV.Wiratna Sujarweni (2014).

(2) Uji Reabilitas

Reliabilitas merupakan ukuran suatu kestabilan dan konsistensi responden

dalam menjawab hal yang berkaitan dengan konstruk-konstruk pertanyaan yang merupakan dimensi suatu variabel dan disusun dalam suatu bentuk kuesioner.

Alat ukur yang akan digunakan adalah cronbachalpha melalui program komputer

Excel Statistic Analysis \& SPSS. Reliabilitas suatu konstruk variabel dikatakan

baik jika memiliki nilai cronbachalpha $>0,60$ (Bhuono Agung Nugroho, 2015, h. 72).

Uji Asumsi Klasik

1. Uji Normalitas 
Uji Kolmogorov Smirnov merupakan pengujian normalitas yang banyak dipakai, terutama setelah adanya banyak

program statistik yang beredar. Kelebihan dari uji ini adalah

sederhana dan tidak menimbulkan perbedaan persepsi di antara

satu pengamat dengan pengamat yang lain, yang sering terjadi

pada uji normalitas dengan menggunakan grafik.

Konsep dasar dari uji normalitas Kolmogorov Smirnov adalah

dengan membandingkan distribusi data (yang akan diuji normalitasnya) dengan distribusi normal baku.

\section{Uji Multikolineriatas}

Uji multikolinearitas digunakan untuk menguji apakah dalam model regresi ditemukan ada atau tidaknya korelasi

antara variabel bebas. Jika terjadi 85 kolerasi, maka dinamakan

terdapat problem multikolinieritas. Model regresi yang baik

seharusnya tidak terjadi kolerasi diantara variabel independen. Jika terbukti ada multikolinieritas, sebaiknya salah satu independen yang ada dikeluarkan dari model, lalu pembuatan model regresi diuang 
kembali (Singgih Santoso, 2010:234). Untuk mendeteksi ada

tidaknya multikolinieritas dapat dilihat dari besaran Variance

Inflation Factor (VIF)dan Tolerance. Pedoman suatu model regresi yang bebas multikolinieritas adalah mempunyai angka tolerance

mendekati 1 .

\section{Uji Heterokedasitas}

Uji heteroskedastisitas bertujuan untuk menguji apakah dalam sebuah model regresi, terjadi ketidaksamaan

varians atauresidual dari satu pengamatan ke pengamatan yang

lain.

Menurut Gujarati (2012:406) untuk menguji ada tidaknya heteroskedastisitas digunakan uji-rank Spearman yaitu dengan

mengkorelasikan variabel independen terhadap nilai absolut dari

residual (error). Untuk mendeteksi gejala uji heteroskedastisitas, maka dibuat persamaan regresi dengan asumsi tidak ada heteroskedastisitas kemudian menentukan nilai absolutresidual, selanjutnya meeregresikan nilai absolute residual diperoleh sebagai variabel dependen serta dilakukan regresi dari variabel independen. Jika nilai Sig $>0,05$ Maka tidak terjadi 
Heteroskedastisitas, dan apabila Sig $<0,05$ Maka terjadi Heteroskedastisitas.

(4)

Uji Regresi Linear Berganda

Regresi diartikan sebagai suatu teknik analisis data yang digunakan untukmencari pengaruh anatara dua variabel atau lebih. Variabel yang dimaksudkandalam hal ini adalah variabel bebas yang biasa disimbolkan dengan X danvariabel terikat yang dismbolkan dengan Y. Analisis regresi bergandadigunakan untuk mencari pengaruh antara dua atau lebih variabel bebasterhadap satu variabel terikat, (Sugiyono, 2012 : 277). Menurut (Sarwono, 2011 : 66) analisis regresi linear berganda mengestimasikan besarnyakoefisien-koefisien yang dihasilkan oleh yang bersifat linear yang melibatkandua variabel bebas untuk digunakan sebagai alat prediksi besarnya nilaivariabel tergantung. Persamaan regresi berganda sebagai berikut:

$Y=a+b 1 X 1+b 2 X 2+e$

Keterangan:

$\mathrm{Y}=$ Variabel terikat

$\mathrm{X} 1$ = Variabe1 bebas

X2 = Variabe1 bebas

$\mathrm{a}=$ Konstanta

$\mathrm{b}=$ koefisien regresi

$\mathrm{e}=$ error

Model ini kemudian diaplikasikan dengan an ini sebagai berikut :

$\mathrm{Y}=$ kiner ja

$\mathrm{X} 1=$ disiplin 


$$
\mathrm{X} 2 \text { = lingkungan kerja }
$$

\section{Rancangan Uji Hipotesis}

1. Uji T (parsial)

Uji T. Uji ini digunakan untuk menguji secara parsial masing-masing

variabel. Hasil uji $t$ dapat dilihat pada tabel coefficients pada kolom sig (significance). Jika probabilitas nilai t atau signifikansi $<0,05$, maka dapat dikatakan bahwa terdapat pengaruh antara variabel bebas terhadap variabel

terikat secara parsial. Namun, jika probabilitas nilai t atau signifikansi 0,05 , maka dapat dikatakan bahwa tidak terdapat pengaruh yang signifikan antara

masing-masing variabel bebas terhadap variabel terikat, (Sugiyono, 2011).

2.

$$
\text { Uji F (Simultan) }
$$

Uji F. Uji ini digunakan untuk mengetahui pengaruh variabel bebas

secara bersama-sama (simultan) terhadap variabel terikat. Signifikan berarti hubungan yang terjadi dapat berlaku untuk populasi. Penggunaan tingkat signifikansinya

beragam, tergantung keinginan peneliti, yaitu $0,01(1 \%) ; 0,05$

$$
\text { dan }
$$$$
0,10
$$

(10\%). Hasil uji F dilihat dalam tabel ANOVA dalam kolom sig. Sebagai

contoh, 
kita menggunakan taraf signifikansi 5\% $(0,05)$, jika nilai probabilitas $<0,05$, maka dapat dikatakan terdapat pengaruh yang signifikan secara bersama-sama

antara variabel bebas terhadap variabel terikat. Namun, jika nilai signifikansi

0, 05 maka tidak terdapat pengaruh yang signifikan secara bersamasama antara

variabel bebas terhadap variabel terikat.

\section{HASIL DAN PEMBAHASAN}

\section{Hasil Penelitian}

Pada penelitian ini teknik analisis data yang digunakan adalah regresi linear berganda. Hasil analisis regresi linear berganda yang telah dilakukan dengan menggunakan bantuan program Statistical Product and Service Solution (SPSS versi 23) adalah sebagai berikut :

a. Uji Validitas

\section{Tabel 1}

Kesimpulan Uji Validitas Corrected Item-Total Correlation

\begin{tabular}{|l|l|l|l|}
\hline \multicolumn{5}{|c|}{ Hasil Uji Validitas Variabel X1, X2 dan Y } \\
\hline $\begin{array}{l}\text { No Butir } \\
\text { Soal }\end{array}$ & Rhitung & rtabel 5\%(110) & Kriteria \\
\hline 1 & 0,419 & 0,186 & Valid \\
\hline 2 & 0,367 & 0,186 & Valid \\
\hline 3 & 0,383 & 0,186 & Valid \\
\hline 4 & 0,424 & 0,186 & Valid \\
\hline 5 & 0,423 & 0,186 & Valid \\
\hline 6 & 0,393 & 0,186 & Valid \\
\hline
\end{tabular}




\begin{tabular}{|l|l|l|l|}
\hline 7 & 0,462 & 0,186 & Valid \\
\hline 8 & 0,384 & 0,186 & Valid \\
\hline 9 & 0,483 & 0,186 & Valid \\
\hline 10 & 0,617 & 0,186 & Valid \\
\hline 11 & 0,275 & 0,186 & Valid \\
\hline 12 & 0,300 & 0,186 & Valid \\
\hline
\end{tabular}

Berdasarkan hasil uji validitas menunjukkan bahwa seluruh nilai rhitung $>$ rtabel, dengan demikian seluruh instrumen kuesioner telah valid dan dapat digunakan dalam penelitian.

Tabel 2

\section{Hasil Uji Reliabilitas Disiplin}

\begin{tabular}{|c|c|c|}
\hline \multicolumn{3}{|c|}{ Reliability Statistics } \\
\hline $\begin{array}{c}\text { Cronbach's } \\
\text { Alpha }\end{array}$ & $\begin{array}{l}\text { Cronbach's } \\
\text { Alpha Based on } \\
\text { Standardized } \\
\text { Items }\end{array}$ & $\mathrm{N}$ of Items \\
\hline ,612 & ,622 & 4 \\
\hline
\end{tabular}

\section{Sumber : hasil perhitungan SPSS Versi 25 Tahun 2020}

Berdasarkan hasil uji reliabilitas untuk variabel X1 (Disiplin), didapati hasil bahwa butir pernyataan pada kuesioner untuk variabel X1 telah reliabel dan dapat digunakan dalam penelitian. Hal ini terlihat dari nilai Cronbach's Alpha yang lebih besar dari $0,6(0,612>0,6)$.

Tabel 3

\section{Hasil Uji Reliabilitas Lingkungan Kerja}

\begin{tabular}{c|c|c}
\multicolumn{3}{c}{ Reliability Statistics } \\
& Cronbach's & \\
& Alpha Based on & \\
Cronbach's & Standardized & \\
Alpha & Items & N of Items \\
\hline
\end{tabular}




,615 3

\section{Sumber : hasil perhitungan SPSS Versi 25 Tahun 2020}

Berdasarkan hasil uji reliabilitas untuk variabel X2 (Lingkungan Kerja), didapati hasil bahwa butir pernyataan pada kuesioner untuk variabel X2 telah reliabel dan dapat digunakan dalam penelitian. Hal ini terlihat dari nilai Cronbach's Alpha yang lebih besar dari 0,6 $(0,615>0,6)$.

\section{Tabel 4}

\section{Hasil Uji Reliabilitas Lingkungan Kerja}

\section{Reliability Statistics}

\begin{tabular}{r|r|r}
\multicolumn{1}{c|}{$\begin{array}{c}\text { Cronbach's } \\
\text { Cronbach's } \\
\text { Alpha }\end{array}$} & $\begin{array}{c}\text { Alpha Based on } \\
\text { Standardized } \\
\text { Items }\end{array}$ & \\
\hline, 645 & N of Items \\
\hline
\end{tabular}

\section{Sumber : hasil perhitungan SPSS Versi 25 Tahun 2020}

Berdasarkan hasil uji reliabilitas untuk variabel Y (Kinerja), didapati hasil bahwa butir pernyataan pada kuesioner untuk variabel Y telah reliabel dan dapat digunakan dalam penelitian. Hal ini terlihat dari nilai Cronbach's Alpha yang lebih besar dari $0,6(0,645>0,6)$.

Tabel 5

Hasil Uji Normalitas

One-Sample Kolmogorov-Smirnov Test

\begin{tabular}{llr} 
& & \multicolumn{1}{c}{$\begin{array}{c}\text { Unstandardized } \\
\text { Residual }\end{array}$} \\
\hline $\mathrm{N}$ & & \multicolumn{1}{c}{112} \\
\hline Normal Parameters & Mean &, 0000000 \\
\cline { 2 - 3 } & Std. Deviation & 2,18006562 \\
\hline
\end{tabular}




\begin{tabular}{llr}
\hline Most Extreme Differences & Absolute &, 193 \\
\cline { 2 - 3 } & Positive &, 193 \\
\cline { 2 - 3 } & Negative &,- 134 \\
\hline Test Statistic & &, 193 \\
\hline Asymp. Sig. (2-tailed) & &, $063^{c}$ \\
\hline
\end{tabular}

a. Test distribution is Normal.

b. Calculated from data.

c. Lilliefors Significance Correction.

\section{Sumber : hasil perhitungan SPSS Versi 25 Tahun 2020}

Berdasarkan tabel One Sample Kolmogorov - Smirnov uji normalitas diatas diketahui nilai signifikansi 0,063 > 0,05, maka dapat disimpulkan bahwa nilai residual berdistribusi normal.

\section{Tabel 6}

\section{Hasil Uji Multikolinearitas}

\begin{tabular}{|c|c|c|c|c|c|c|c|c|}
\hline \multicolumn{9}{|c|}{ Coefficients $^{a}$} \\
\hline \multicolumn{2}{|c|}{ Model } & \multicolumn{2}{|c|}{$\begin{array}{l}\text { Unstandardized } \\
\text { Coefficients }\end{array}$} & $\begin{array}{c}\text { Standardiz } \\
\text { ed } \\
\text { Coefficients } \\
\text { Beta }\end{array}$ & $\mathrm{T}$ & Sig. & \multicolumn{2}{|c|}{$\begin{array}{l}\text { Collinearity } \\
\text { Statistics } \\
\text { Toleranc } \\
\text { e }\end{array}$} \\
\hline 1 & (Constant) & 22,644 & 2,873 & & 7,883 & ,000 & & \\
\hline & Disiplin & ,121 & , 123 & ,093 & ,989 & ,325 & ,999 & 1,001 \\
\hline & $\begin{array}{l}\text { Lingkungan } \\
\text { Kerja }\end{array}$ &,- 231 & ,162 &,- 135 & $-1,429$ & ,156 & ,999 & 1,001 \\
\hline
\end{tabular}

a. Dependent Variable: Kinerja

\section{Sumber : hasil perhitungan SPSS Versi 25 Tahun 2020}

Berdasarkan hasil dari uji multikolinearitas dengan output tabel Coeffients ${ }^{a}$ didapatkan hasil dari Variance Inflation Factor (VIF) senilai 1,001. Maka dapat disimpulkan bahwa VIF 1,001 < 10,00 tidak terjadi multikolinearitas. 


\section{Tabel 7}

\section{Hasil Uji Heteroskedastisitas}

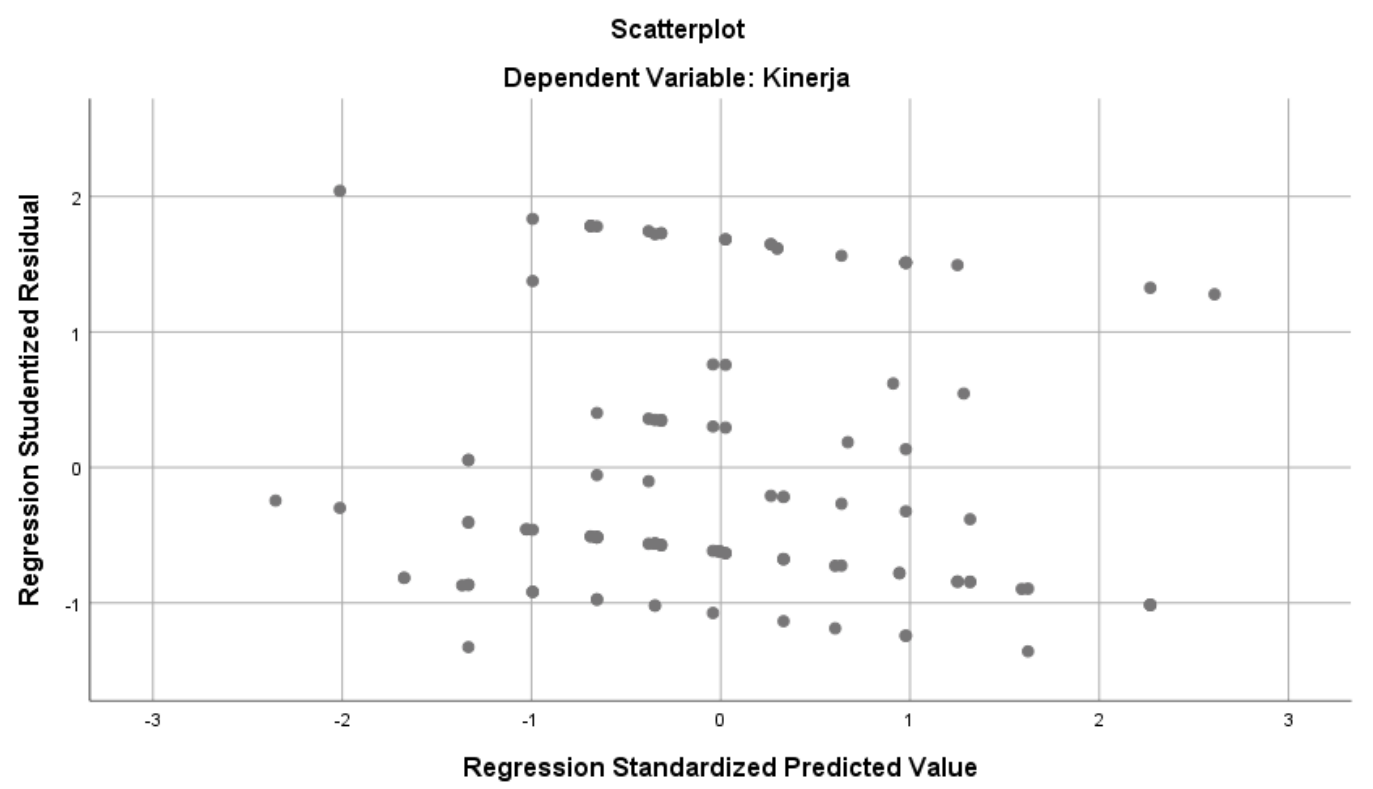

Sumber : hasil perhitungan SPSS Versi 25 Tahun 2020

Berdasarkan hasil uji Scatterplot diatas dapat terlihat bahwa titik titik tersebar merata dan tidak membentuk pola bergelombang melebar kemudian menyempit dan melebar kembali. Dengan demikian dapat disimpulkan bahwa tidak terjadi Heterokedastisitas dalam model regresi.

Tabel 8

\section{Uji Regresi Linear Berganda}

\section{Coefficients $^{a}$}

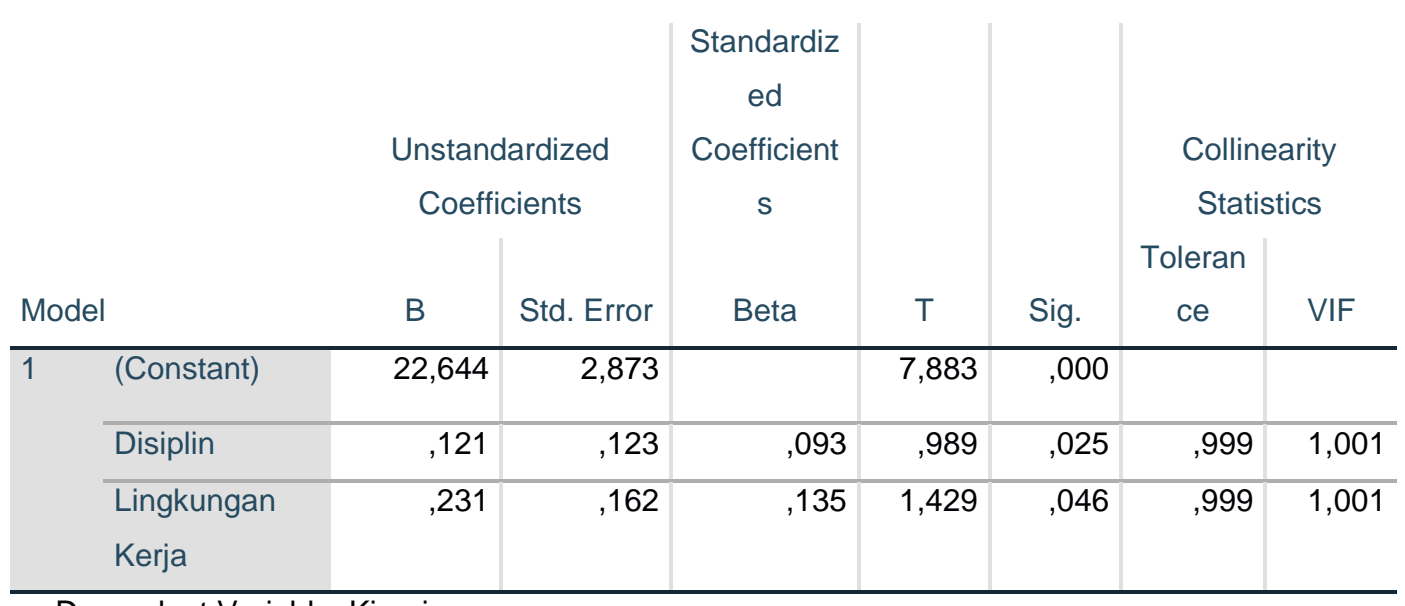

a. Dependent Variable: Kinerja

Sumber : hasil perhitungan SPSS Versi 25 Tahun 2020 
Berdasarkan tabel diatas maka dibuat persamaan regresi sebagai berikut :

$\mathrm{Y}=\mathrm{b} 1 \mathrm{X} 1+\mathrm{b} 2 \mathrm{X} 2$

$\mathrm{Y}=0,093 \mathrm{X} 1+0,135 \mathrm{X} 2$

Dari persamaan regresi linear berganda dapat dijelaskan sebagai berikut :

1. Nilai koefisien regresi (b1) untuk variabel disiplin adalah (b1 =0,093) ini menunjukkan bahwa jika disiplin pegawai ditingkatkan, maka akan meningkat peningkatan kinerja pegawainya. Hasil signifikan sebesar 0,025, hal ini berarti variabel disiplin mempunyai pengaruh positif terhadap kinerja pegawai Satuan Polisi Pamong Praja Kota Prabumulih .

2. Nilai koefisien regresi (b2) untuk variabel lingkungan kerja adalah (b2 = $0,135)$ ini menunjukkan bahwa jika lingkungan kerja ditingkatkan atau di perbaiki, maka akan meingkat peningkatan kinerjanya. Hasil signifikan sebesar 0,046, hal ini berarti variabel lingkungan kerja mempunyai pengaruh positif terhadap kinerja pegawai Satuan Polisi Pamong Praja Kota Prabumulih

\section{Tabel 9}

\section{Hasil Uji t (Parsial)}

\begin{tabular}{|c|c|c|c|c|c|c|c|c|}
\hline \multicolumn{9}{|c|}{ Coefficients $^{a}$} \\
\hline \multirow{2}{*}{\multicolumn{2}{|c|}{ Model }} & \multicolumn{2}{|c|}{$\begin{array}{c}\text { Unstandardized } \\
\text { Coefficients }\end{array}$} & \multirow{2}{*}{$\begin{array}{c}\text { Standardiz } \\
\text { ed } \\
\text { Coefficient } \\
\text { s } \\
\text { Beta }\end{array}$} & \multirow[b]{2}{*}{$\mathrm{T}$} & \multirow[b]{2}{*}{ Sig. } & \multicolumn{2}{|c|}{$\begin{array}{l}\text { Collinearity } \\
\text { Statistics }\end{array}$} \\
\hline & & $B$ & Std. Error & & & & $\begin{array}{c}\text { Toleran } \\
\text { ce }\end{array}$ & VIF \\
\hline 1 & (Constant) & 22,644 & 2,873 & & 7,883 & ,000 & & \\
\hline & Disiplin & ,121 & ,123 & ,093 & ,989 & ,025 & ,999 & 1,001 \\
\hline & $\begin{array}{l}\text { Lingkungan } \\
\text { Kerja }\end{array}$ & ,231 & ,162 & ,135 & 1,429 & ,046 & ,999 & 1,001 \\
\hline
\end{tabular}

a. Dependent Variable: Kinerja

Sumber : hasil perhitungan SPSS Versi 25 Tahun 2020

\section{Pengujian Hipotesis H1 :}


Diketahui nilai sig. Untuk pengaruh X1 terhadap Y adalah sebesar 0,025 $<0,05$ sehingga dapat disimpulkan bahwa $\mathrm{H} 1$ diterima dan terdapat pengaruh $\mathrm{X} 1$ terhadap Y.

\section{Pengujian Hipotesis H2 :}

Diketahui nilai sig. Untuk pengaruh X2 terhadap $\mathrm{Y}$ adalah sebesar $0,46<0,05$ sehingga dapat disimpulkan bahwa $\mathrm{H} 2$ diterima dan terdapat pengaruh $\mathrm{X} 2$ terhadap Y.

\section{Tabel 10}

\section{Hasil Uji f (Simultan)}

\begin{tabular}{llr|r|r|r|r}
\multicolumn{2}{c}{ ANOVA $^{\text {a }}$} & & \\
Model & & Sum of Squares & Df & Mean Square & F & Sig. \\
\hline 1 & Regression & 514,166 & 2 & 237,083 & 21,463 &, $006^{b}$ \\
\cline { 2 - 7 } & Residual & 527,548 & 109 & 4,840 & & \\
\cline { 2 - 7 } & Total & 541,714 & 111 & & & \\
\hline
\end{tabular}

a. Dependent Variable: Kinerja

b. Predictors: (Constant), Lingkungan Kerja, Disiplin

\section{Pengujian Hipotesis H3 :}

Berdasarkan output diatas diketahui nilai signifikasi untuk pengaruh $\mathrm{X} 1$ dan $\mathrm{X} 2$ secara simultan terhadap $\mathrm{Y}$ adalah sebesar $0,006<0,05$. Sehingga dapat disimpulkan bahwa H3 diterima yang berarti terdapat pengaruh X1 dan X2 secara simultan terhadap $\mathrm{Y}$.

\section{Pembahasan}

\section{(1)Pengaruh Displin Terhadap Kinerja Pegawai}

Hasil penelitian ini menunjukkan bahwa Disiplin terdapat pengaruh yang signifikan terhadap Kinerja Pegawai Satuan Polisi Pamong Praja Kota Prabumulih. Semakin tinggi disiplin pegawai maka semakin baik pula kinerja yang dihasilkan. 
Disiplin yang dimiliki pegawai Satuan Polisi pamong Praja Kota Prabumulih kurang maksimal dan belum menggunakan jam kerja secara optimal. Pegawai yang memiliki disiplin kerja yang tinggi diharapkan agar mampu berusaha semaksimal mungkin untuk menyelesaikan pekerjaannya, sehingga dapat menghasilkan kinerja yang optimal bagi sebuah instansi. Menurut Keith Davis (1985) disiplin kerja dapat diartikan sebagai pelaksanaan manajemen untuk memperteguh pedoman-pedoman organisasi. Disiplin kerja adalah suatu alat yang digunakan para manajer untuk berkomunikasi dengan bawahannya agar mereka bersedia meningkatkan kesdaran seseorang mentaati semua peraturan dan normanorma sosial yang berlaku.

Dari penjelasan tersebut dapat disimpulkan bahwa adanya disiplin kerja yang baik maka akan menghasilkan kinerja pegawai yang baik pula, sebaliknya jika tidak adanya disiplin kerja pada pegawai Satuan Polisi Pamong Praja Kota Prabumulih maka akan menghasilkan kinerja tang kurang baik pula. Penelitian ini juga didukung dengan penelitian yang dilakukan oleh Rina Dwining Tyas dan Bambang Swasto (2018) yang menunjukkan bahwa disiplin kerja secara parsial berengaruh secara signifikan terhadap kinerja karyawan dengan nilai t sebesar 0,000 .

\section{(2) Pengaruh Lingkungan Kerja Terhadap Kinerja Pegawai}

Hasil penelitian ini menunjukkan bahwa Lingkungan Kerja terdapat pengaruh yang signifikan terhadap Kinerja Pegawai Satuan Polisi Pamong Praja Kota Prabumulih. Semakin baik dan nyaman lingkungan kerja maka semakin baik pula kinerja yang dihasilkan.

Lingkungan kerja pegawai Satuan Polisi Pamong Praja Kota Prabumulih belum mencerminkan lingkungan yang nyaman bagi pegawai, hal ini dapat dilihat dari suasana kerja yang tidak kondusif contonya belum adanya ruang khusus bagi pegawai yang merokok (smoking area) sehingga mengganggu pegawai yang tidak merokok, hubungan antar rekan kerja baik dengan pimpinan maupun rekan sesama bawahan, tetapi dalam hal fasilitas kerja pegawai Satuan Polisi Pamong Praja Kota Prabumulih sudah cukup nyaman dengan adanya pemasangan free wifi bagi pegawai. 
Dari penjelasan tersebut dapat disimpulkan bahwa adanya lingkungan kerja yang baik maka akan menghasilkan kinerja pegawai yang baik, sebaliknya jika lingkunga kerja kurang baik maka kinerja pegawai akan kurang baik pula. Penelitian ini didukung dengan penelitian yang dilakukan oleh Rima Dwing Tyas dan Bambang swasto (2018) bahwa lingkungan kerja secara parsial berpengaruh signifikan terhadap kinerja karyawan dengan nilai signifikansi t sebesar 0,000.

\section{(3) Pengaruh Secara Simultan}

Hasil penelitian ini menunjukkan bahwa disiplin dan lingkungan kerja mempunyai pengaruh yang signifikan terhadap kinerja pegawai. Kinerja adalah hasil kerja yang dapat dicapai oleh seseorang atau sekelompok orang dalam suatu organisasi, sesuai dengan wewenang dan tanggung jawab masing - masing, dalam upaya mencaai tujuan organisasi bersangkutan secara legal, tidak melanggar hukum dan sesuai dengan moral maupun etika (Prawirosentono,1991). Kedisplinan harus ditegakkan dalam suatu organisasi, tanpa disiplin pegawai yang baik, sulit organisasi untuk mewujudkan tujuannya. Jadi, kedisplinan adalah kunci suatu organisasi dalam mencapai tujuannya. Disiplin juga dapat diartikan sebagai proses latihan pengendalian diri untuk bekerja efektif,efesien,dan produktif. Tujuan disiplin adalah latihan pengendalian diri untuk meningkatkan prestasi kerja sehingga tercapai tujuan organisasi. Lingkungan kerja yang baik dan nyaman akan sangat berpengaruh pada kinerja pegawainya, Menurut Robbins (2003) lingkungan adalah lembaga-lembaga atau kekuatan-kekuatan diluar yang berpotensi mempengaruhi kinerja organisasi, lingkungan dirumuskan menjadi dua yaitu lingkungan umum dan lingkungan khusus. Lingkungan umum adalah segala sesuatu di luar organisasi yang memilki potensi untuk mempengaruhi organisasi. Lingkungan ini berupa kondisi sosial dan teknologi. Sedangkan lingkungan khusus adalah bagian lingkungan yang secara langsung berkaitan dengan pencapaian sasaran-sasaran sebuah organisasi. Dari penjelasan tersenut dapat disimpulkan bahwa dengan adanya disiplin kerja yang tinggi serta suasana lingkungan kerja yang kondusif maka akan menghasilkan kinerja pegawai yang baik. Penelitian ini juga didukung oeh penelitian yang dilakukan oleh Zainul Hidayat,MM dan Muchamad taufiq,MH (2012) menyatakan bahwa ada pengaruh 
yang signifikan dari variabel lingkungan kerja dan disiplin kerja dan motivasi kerja secara simultan berpengaruh terhadap kinerja karyawan.

\section{SIMPULAN DAN SARAN}

\section{Simpulan}

Berdasarkan hasil analisis penelitian dan pembahasan tentang pengaruh disiplin dan lingkungan kerja terhadap kinerja pegawai Satuan Polisi Pamong Praja Kota Prabumulih, maka dapat disimpulkan sebagai berikut:

1. Disiplin (X1) berpengaruh secara signifikan terhadap kinerja pegawai (Y) Satuan Polisi Pamong Praja Kota Prabumulih. Hal ini dapat dibuktikan berdasarkan hasil uji t (parsial) pengaruh X1 terhadap Y adalah sebesar 0,025 $<0,05$ sehingga dapat disimpulkan bahwa hipotesis diterima dan terdapat pengaruh X1 terhadap $\mathrm{Y}$. Jadi apabila pegawai dapat bekerja sesuai denganstandar kerja yang sudah ditentukan, maka kinerja pegawai Satuan Polisi Pamong Praja Kota Prabumulih akan mengalami peningkatan.

2. Lingkungan Kerja (X2) berpengaruh secara signifikan terhadap kinerja pegawai (Y) Satuan Polisi Pamong Praja Kota Prabumulih. Hal ini dapat dibuktikan berdasarkan hasil uji t (parsial) pengaruh X2 terhadap Y adalah sebesar 0,46 $<0,05$ sehingga dapat disimpulkan bahwa $\mathrm{H} 2$ diterima dan terdapat pengaruh X2 terhadap Y. Jadi, lingkungan kerja yang kondusif akan sangan membantu pegawai dalam meningkatkan kinerjanya, karena pegawai merasa nyaman dalam bekerja.

3. Disiplin (X1) dan Lingkungan Kerja (X2) berpengaruh secara signifikan terhadap kinerja pegawai (Y) Satuan Polisi Pamong Praja Kota Prabumulih. Hal ini dapat dibuktikan berdasarkan hasil uji f (simultan) pengaruh X1 dan $\mathrm{X} 2$ secara simultan terhadap $\mathrm{Y}$ adalah sebesar $0,006<0,05$. Sehingga dapat disimpulkan bahwa $\mathrm{H} 3$ diterima yang berarti terdapat pengaruh $\mathrm{X} 1$ dan $\mathrm{X} 2$ secara simultan terhadap Y. Apabila sebuah organisasi ingin meningkatkan kinerja pegawai, maka diperlukan tingkat disiplin yang tinggi dan menciptakan lingkungan kerja yang nyaman dan kondusif. Dengan tingkat disipli dan lingkungan kerja yang nyaman, memunginkan pegawai untuk 
menyelsaikan pekerjannya dengan baik, sehingga hasil kerja yang dihasilkan oleh pegawai Satuan Polisi Pamong Praja Kota Prabumulih akan maksimal.

\section{Saran}

Berdasarkan hasil penelitian, pembahasan dan kesimpulan yang diperoleh, maka saran yang dapat diberkan adalah sebagai berikut ;

1. Bagi Instansi Terkait

Satuan Polisi Pamong Praja Kota Prabumulih sebaiknya lebih meningkatkan tingkat disiplin pada pegawai. Pemimpin sebaiknya perlu mengawasi, menegakkan peraturan dan memberikan sanksi yang tegas kepada pegawai, supaya pegawai dapat lebih disiplin, rajin dan efektif dalam menggunakan waktu kerjanya. Selain itu sebaiknya instansi juga perlu memperhtikan faktor lingkungan kerja yang nyaman dan kondusif misalnya memasang wifi pada pos - pos jaga dan sebagainya.

2. Bagi Peneliti Selanjutnya

Peneliti selanjutnya dapat mengembangkan penelitian ini dengan menambah variabel bebas lainnya dalam melihat pengaruh kinerja sehingga hasilnya yang dicapai lebih optimal dan dapat memperluas pengatahuan atau wawasan.

\section{DAFTAR PUSTAKA}

Arianto, Dwi Agung Nugroho. 2013. Pengaruh Kedisiplinan, Lingkungan Kerja dan Buday Kerja Terhadap Kinerja Tenaga Pengajar Yaspenlub Demak.

Dewi Jumpana, Ratna. 2017. Analisis Kinerja Pegawai Satuan Polisi Pamong Praja Kota Prabumulih. Universitas Sjakhyakirti Palembang.

Fathoni, Abdurrahmat. 2006 . Manajemen Sumber Daya Manusia, Bandung : Rineka Cipta.

Juliadi (2018) Pengaruh Disiplin Kerja dan Lingkungan Kerja Terhadap Kinerja Pegawai Pada Inspektorat Kabupaten Oki. Universitas Sjakhyakirti, Palembang.

Nela Pima Rahmawanti, Bambang Swasto, dan Arik Prasetya (2014) Pengaruh Lingkungan Kerja Terhadap Kinerja Karyawan. 
Novida Pasri Faerzadiana, H. Eddy K. Soegiarto dan Titin Ruliana. 2016. Pengaruh Disiplin Kerja dan Lingkungan Kerja Terhadap Kinerja Pegawai Pada Kantor Badan Kepegawaian daerah Kabupaten Kutai Barat. Jurnal.

Parlinda dan Wahyuddin. 2001. Pengaruh Kepemimpinan, Motivasi, Pelatihan dan Lingkungan Kerja pada Perusahaan daerah Air Minum Kota Surakarta. Universitas Muhammadiyah Surakarta.

Pakhpahan D, Rico. 2017. Pengaruh Disiplin Kerja Dan Lingkungan Kerja Terhadap Kinerja Karyawan (studi kasus pada CV. Hamparan Seaga). Universitas Negeri Yogyakarta.

Pratama Nur, Aditya ( 2016) Pengaruh Lingkungan Kerja dan Disiplin Kerja Terhadap Kinerja Karyawan PT. Razers Brothers. Universitas Negeri Yogyakarta. Yogyakarta.

Rakasiwi, Galih (2014) Pengaruh Motivasi,Kepuasan Kerja dan Disiplin Kerja Terhadap Kinerja Pegawai (studi empiris pada Satuan Polisi Pamong Praja kabupaten Karanganyar) - Naskah Publikasi

Rr. Dewi Handayani. 2015. Pengaruh Motivasi Kerja dan Lingkungan Kerja Terhadap Kinerja Karyawan Perpustakaan Institut Teknologi Sepuluh November (ITS) Surabaya.

Sulisdiani, Indah. 2012. Kinerja Satuan Polisi pamong Praja Dalam Penertiban Pedagang Kaki Lima (PKL) di Kota Pontianak.

Soetjipto, BW. 2004. Manajemen Sumber Daya Manusia. Yogyakarta : Penerbit Amara Book.

Widari, Tri. 2016 . Pengaruh Disiplin dan Lingkungan Kerja Terhadap Kinerja Pegawai ( Studi pada Badan Kepegawaian Daerah Daerah Istimewah Yogyakarta). Universitas Negeri Yogyakarta, Yogyakarta

Yudiningsih, Ni Made Dian, Fridayana Yudiatmaja dan Ni Nyoman Yulianthini. 2016. Pengaruh Lingkungan Kerja dan Disiplin Kerja Terhadap Kinerja Pegawai. 
JURNAL MANAJEMEN KOMPETEN

Vol. 3 No. 2 Desember 2020, 47-69 